\title{
Assessment of Community Perception on Climate Change in Selected Areas of Arbaminch District, Southern Ethopia
}

\author{
Zenebe Reta ${ }^{*}$ Tigist Girum \\ Bedele College of Agriculture and forestry, Mettu University, P.O. Box 318, Bedele, Ethiopia
}

\begin{abstract}
This study was carried out at Shara Kebele of Arba Minch district with the objective of assessing the perception and attitude of local community on climate change. Both primary and secondary data sources were used. A semistructured questionnaire was applied to collect primary data through face to face interview. Analysis of the data was done by using descriptive statistics and the results are presented in tables and percentages and descriptive way. This generates evidences helpful to support actions and decisions relating to climate change mitigation and adaptation at the study area and similar to other areas in the region. The result showed that the local communities' awareness to climate change and its impact is less. By contrast, experts are more awarded about climate change and its impact was observed. Climate change and its effect should be addressed through training, discussion and adoption of best climate change mitigation practices.
\end{abstract}

Keywords: Climate change, Community perception, mitigation, adaptation

DOI: $10.7176 / \mathrm{JEES} / 9-1-04$

\section{INTRODUCTION}

Climate change mean a change in global or regional climate patterns, in particular a change apparent from the mid to late 20th century onwards and attributed largely to the increased levels of atmospheric carbon dioxide produced by the use of fossil fuels. Climate change is one of the global changes of $21^{\text {st }}$ Century. The adverse impacts of climate change are affecting all countries, especially the developing countries where Africa is the most vulnerable region to climate change because of the low adaptive capacity of its population resulting mainly from extreme poverty, frequent natural disasters such as droughts and floods, and poor agriculture which depend on rainfall. The main impacts of climate change are on the Water resources, food security and agricultural production, natural resources, biodiversity, and human health (Dievudonne, 2001as cited in Huq, 2003). Severe and/ or prolonged droughts in dry lands have seriously affected agriculture and wildlife and cussed many severe malnutrition and deaths. Ethiopia is one of poorest and highly populated countries in the Horn region of Africa which is adversely affected by the impact of climate change (Haakansson, 2009).

The national program on how Ethiopia can adapt to climate change states that repeated droughts, hunger and floods are among the most serious problems affecting millions of Ethiopians almost every year (NMSA, 2007). Rainfall variability and associated drought have been major cause of the country food shortage and famine because agriculture is the foundation of the national economy and constitutes the primary source of livelihood for the overwhelming majority of the population. Climate change impacts aggravated poverty, health problems, food insecurity, and other social and environmental problems facing the country (NCCF, 2009).

Local community's perception (LCP) about their environment is critical because their perception fundamentally determine the socioeconomic activates in their locality. Successfully mitigation and adapting to climate change require changes in the behavior of billions of human being, who each day make individual choices that collectively have enormous impact on the earth's climate(Brehin,2003: cited in Adane, 2009).

Thus by keeping in view the problem of climate change and its severity especially on poor country like Ethiopia it necessitate to conduct research at different levels so that people's perception towards climate change should be studied which can form the foundation for the policy makers for its mitigation. The proposed research project is also a same type of study that is restricted to small area called Shara Kebele and has been formulated with different objectives. . Therefore, capturing the perception of people in general and Shara community in particular for development activity and planning appropriate adaptation strategy. This study will serves as the source information or reference material for people those who will be interested to do relative study on this different area for the future and to investigate the perception of community on climate change and adaptation activities carried out by the local people.

Therefore, the objective of this study was;

$>$ To assess the awareness and attitude of community on climate change in the study area,

$>$ To assess the impacts of climate change in the study area,

$>$ To identify adaptation strategies employed by the community to cope with the changing climate.

\section{MATERIALS AND METHODS}

2.1. General Description of study area

The study was conducted in Gamo Gofa Zone of Arba Minch Zuria woreda particularly in Shara Keble. Shara 
Keble is one of the 29 Kebeles of Arba Minch Zuria woreda, which is located about $495 \mathrm{~km}$ south west of Addis Ababa and 10km north east of Arba Minch town. The altitude of the Kebele ranges from 1300-1800mmabove sea level. Climatically characterized by bi modal rain fall pattern. The annual rain fall resaved within the, Study area range $300-1200 \mathrm{~mm}$ and the mean annual temperature ranges between 15-25 degree Celsius $\left(25 \mathrm{c}^{\circ}\right)$. The mean rain seasons are from March to May and June to September. The agro Ecological Zone of This Keble is characterized by Woyna dega and Kola. Demographically the study area has high population density compared to other areas. According to population and house hold censes of 2009the total population of the area 10,690 out of which 5238 are males and 5452 are females. Within this population the total households are 2155 . In case of land use system Oxen plough and hoe cultivation are dominant agricultural activities practices by farmers. Totally farming is dominant type of land use totally from 5800 ha of land 990 ha is used for agricultural some people also earn their income from secondary sources such as poultry business etc. In general the majority of the people are depend on agricultural production with main cash crop are banana and mango which are the most dominant in the area .The detailed information regarding area under different land use system is as below:

Table 1, land use system of Shara Keble.

\begin{tabular}{|l|l|}
\hline Land use & Area ha \\
\hline Annual crop production & 610 \\
\hline Perennial crop production & 390 \\
\hline grazing land & 420 \\
\hline Degraded land & 550 \\
\hline Marshal land & 120 \\
\hline Forest land & 3600 \\
\hline Shrub land & 130 \\
\hline Total & 5800 \\
\hline
\end{tabular}

Source: (Sharakebele agricultural office)

Concerning soil type of the district there are two predominant type of soil namely clay and sandy. The fertility status of the ranges from good to good, but has limitation due to susceptibility to water erosion (social field survey 2017).

Concerning vegetation and crops Due to population pressure in present time, most forest areas covered into agricultural land there are both indigenous and exotic species of trees. The main species are Cordiaafricana, Acacia species, Balaniitesaegyeptica, Croton macrostachyus, Ricinuscommunis, Eucalyptus, terminalia brownie, grevillearobusta, Jatrophacurcasand the like. The crop type in the study area includes Zea mays (maize), Mangiferaindica (mango), Moringaoleifera (Moringa), PerseaAmericana (avocado), Carica papaya (Papaya), Coffeearabica (coffee), and the like. More over maize, mango, and banana are more dominant in the area (social field survey, 2017).

\subsection{Methods of data collection}

\subsubsection{Data collection strategies}

A preliminary field survey was conducted to get general information in order to set research design, determine sample size, and identify the adaptation strategies employed by the community to cope with the changing climate. Community based cross sectional study design was used to assess community perception on climate change in the study area. The information that was taken from the sample households was used to avail them at appropriate place to take orientation and to distribute questionnaires. The questionnaire was distributed to reach of the respondents that were selected.

\subsubsection{Sampling method and sample size:}

The Proposed study entitled "To assess the perception of community on climate selectively in Shara Kebele" was carried out at the Shara Kebele. The study was done by using simple random sampling method. The sampling systems were in accordance with different wealth and age groups, male and female headed households. It was conducted in the selected study area by taking sample households. The total households of Shara are 2155 and from these households, 43 households (about $2 \%$ ) were selected as respondents. The further selection of respondents (experts) were done through random sampling techniques for ensuring equal chance of being selected for every household and to minimize any bias to get necessary data and information for the study. The number of household selected for interview was calculated by using the following kurtosis formula.

: $\mathrm{n}=\mathrm{THH}^{*} \mathrm{e}$ or $\mathrm{N}^{*} \mathrm{e}$

Where $\mathrm{n}=$ sample size

$\mathrm{N}=$ total households (THH) (2155)

$\mathrm{e}=$ is the level of precision with the $2 \%$ of sampling intensity was taken due to the of lack budget, time and in availability of other resources.

$\mathrm{n}=\mathrm{THH}^{*} \mathrm{e}$ or $\mathrm{N}^{*} \mathrm{e}$ 


$$
\mathrm{n}=2155^{*} \% \mathrm{\%}=43
$$

\subsubsection{Data collection}

For the purpose of this study, data was obtained from both primary and secondary sources. Primary data was obtained or collected through interview based questionnaires (both open and closed end), direct field observation, and focus group discussion (FGD) with experts in the study area. Secondary data was obtained from published and unpublished documents were used to get enough information that supports the research and its acceptance. On both data collection, special effort such as ensuring the randomness of sampling were employed to control quality of data that wanted to be collect.

\subsubsection{Data analysis}

Both qualitative and quantitative data that was conducted from the sample respondents through survey, questionnaire, interview and observation was organized in a manner which facilities its analysis. The data was analyzed using statistical procedures such as frequency and percentage with using table and descriptive presentation way.

\section{RESULTS.AND DISCUSSSION}

\section{Awareness to climate change among local communities}

The result indicated that from 43 respondents, there were 16 respondents $(37.21 \%)$ awareness to climate change and its impacts. While the other 27 respondents $(62.79 \%)$ less awareness to climate change and its impacts. This is because of lack of training to climate change. The attitude of the local community towards climate change is traditionally measured. As the respondent express their opinion, they assume climate change as the God rath .But natural/human-induced event. Due to this they try to adapt rather than mitigation.

Successfully mitigating and adapting to climate change require changes in the behavior of peoples who each day make individual choices that collectively have enormous impact on the earth's climate. However, very little known about international local community opinion regarding climate change (Berchin,et,al., 2003).

Table 3: Awareness to climate change among local community

\begin{tabular}{|l|l|l|}
\hline community awareness & Frequency & Percent (\%) \\
\hline Awared to climate change & 27 & $62.79 \%$ \\
\hline Not awared to climate change & 16 & $37.2 \%$ \\
\hline Total & 43 & $100 \%$ \\
\hline
\end{tabular}

\section{Vulnerable economic sectors to climate change}

The result shows that agriculture is the most vulnerable economic sector to be affected by climate change. This is because of most of their economy is depend on agriculture. Health is also the more vulnerable sector. The water and forest are the least vulnerable ones compared to agriculture and health. (Table 4). The study Shows that if those sectors are the vulnerable, there will be a severe food scarcity, and the chance of disease spread is occurred. In turn community is affected widely.

Vulnerability assessment based on existing information and rapid assessment are carried out under National adaptation program of action of Ethiopia (NAPA) has Indicated that the most vulnerable sectors to climate variability and change are agriculture, water resources and human health care which is the is the most important sector in the Ethiopia economy (Temesgen, 2007).

Climate change will affect social-economic sectors including water resources, agro-culture, forestry, fisheries and human settlement, ecological systems and human health in many parts of the world, with developing countries being the most vulnerable ones.(IPCC, 2000,)

Table 4: Vulnerable economic sectors which are affected by Climate change

\begin{tabular}{|l|l|l|}
\hline Vulnerable economic sectors & Respondents & Percentage \\
\hline Agriculture & 15 & $34.88 \%$ \\
\hline Water & 4 & $9.3 \%$ \\
\hline Health & 10 & $23.25 \%$ \\
\hline Forest & 6 & $13.95 \%$ \\
\hline Economy & 8 & $18.6 \%$ \\
\hline Total & 43 & $100 \%$ \\
\hline
\end{tabular}

Impact of climate change on agricultural productivity on the study area

The result shows that climate change has effect on agricultural productivity. I.e. Before 1990s maize production per hectare was $80 \mathrm{~kg}$ but now a time it is $30 \mathrm{~kg} / \mathrm{ha}$. This result indicated that from 43 respondents, there were $(62.79 \%)$ respondents their maize agricultural productivity are mostly affected by Climate change while the rest of respondents(37.21\%) were their mango product likely affected by climate change. (Table 5)

Productivity and competitiveness agro-cultural sector is increasingly constrained by temporal and spatial 
variability of climate (NCCF, 2009).

Table5: Impact of climate change on agricultural productivity.

Impact of climate change on agricultural

Productivity

Climate change impact on maize

Climate change impact on mango

Total

\begin{tabular}{|l|l|}
\hline Frequency & Percent \\
\hline 27 & $62.79 \%$ \\
\hline 16 & $37.21 \%$ \\
\hline 43 & $100 \%$ \\
\hline
\end{tabular}

Impact of climate change on health

As the result shows that from 43 respondents, $46.51 \%$ are affected by malaria and about $20.93 \%$ respondents are affected by diarrhea the indicator of this is as a result of climate change the presence of malaria when there is high temperature and the presence of diarrhea disease when water is polluted in their local area. (Table 6).

Climate change will affect human health and wellbeing through a variety of mechanisms. Climate change can adversely affect the availability of fresh water supplies, and the efficiency of local sewerage system. Africa is vulnerable to a number of climate sensitive diseases including malaria, tuber closes and Diarrhea (Guernier, 2004).

Table: 6 Impact of climate change on health

\begin{tabular}{|l|l|l|}
\hline Impact of climate change on health & Frequency & Percent \\
\hline Malaria & 20 & $46.51 \%$ \\
\hline Tuberculosis & 14 & $32.56 \%$ \\
\hline Diarrhea & 9 & $20.93 \%$ \\
\hline Total & 43 & $100 \%$ \\
\hline
\end{tabular}

Awareness of communities about climate change adaptation in the study area

The result indicates that $37.21 \%$ of the respondent used soil water conservation practice $13.95 \%$ of the respondents used improved stoves, $20.93 \%$ of respondents used bio gas fuel and $27.91 \%$ of respondents used short rotation crops used for climate change adaptation, for further information it's explained in the following table

Table: 7 Awareness of community about climate change adaptation.

\begin{tabular}{|l|l|l|}
\hline Awareness to climate change adaptation & Frequency & Percent \\
\hline Improved stoves & 6 & $13.95 \%$ \\
\hline Bio gas fuel & 9 & $20.93 \%$ \\
\hline Soil water conservation & 16 & $37.21 \%$ \\
\hline Short rotation crops & 12 & $27.91 \%$ \\
\hline Total & 43 & $100 \%$ \\
\hline
\end{tabular}

The indigenous knowledge to adaptation climate change in the study area.

As the result indicated there are a lot of mitigation measures to climate change in the area. From those planting tree is the most one. Planting sweet potatoes and using compost are the more used measures. From mitigation measures used in this area afforestation and carbon trade are the least used measures compared to the above one's (Table 8)

Table: 8 Indigenous knowledge to mitigate climate change among local communities

\begin{tabular}{|l|l|l|}
\hline $\begin{array}{l}\text { Indigenous knowledge to climate change } \\
\text { Adaptation }\end{array}$ & Frequency & Percentage \\
\hline Planting tree & 17 & $39.53 \%$ \\
\hline Terracing & 11 & $25.58 \%$ \\
\hline Tolerant plant crop planting & 5 & $11.63 \%$ \\
\hline Sweet potatoes & 5 & $11.63 \%$ \\
\hline Using compost & 5 & $11.63 \%$ \\
\hline Total & 43 & $100 \%$ \\
\hline
\end{tabular}

\section{Mitigation strategies in the study area}

The result shows that there are a lot of mitigation strategies are used in the study area reduce climate change effects. From these expansions of plantation, waste disposal far away from the living area and soil water conservation practices were used in the community. From 40 respondents, there were $67.44 \%$ said that they have plantation mitigation measure in their local area. The other $13.95 \%$ respondent used waste disposal to mitigate climate change, $18.61 \%$ respondents used soil and water conservation practice. (Table: 9 ) 
Table: 9 Mitigation strategies in the study area

\begin{tabular}{|l|l|l|}
\hline Mitigation strategies & Respondent (frequency) & Percentage \\
\hline Plantation & 29 & $67.44 \%$ \\
\hline Waste disposal & 6 & $13.95 \%$ \\
\hline Soil and water conservation practice & 8 & $18.61 \%$ \\
\hline Total & 43 & $100 \%$ \\
\hline
\end{tabular}

Degree of farmers preferred crop and tree species in order to mitigate climate change

The result shows that from 43 respondents, 41.86\%, 23.25\%, 18.6\%, 16.29\% were used wanza, Shola, Grawa,Warka respectively. The main reason of local communities to use these species is because of at winter time they fall their litters and decomposed quickly. As a result in hence soil fertility their roots control soil from wind and water erosion. Regulate soil environment by their moderate climate change and increase crop Yield. They also used grass and grassy crop species which include $23.25 \%, 34.89 \%, 30.23 \%, 11.63 \%$ of desho, boloke, quality protein maize and masho respectively. The main reason of local communities use these species is due to they are fast growing crop and improved variety which comes to mature with in short period of time mainly in 3 months period and able to serve the community when they face food insecurity problem due to impact of climate change. Other coping mechanism used by community is early warning system which provided to them from the respective meteorological agency through the their Keble administration enabling them to escape out of the impact even if they are not able to reduce degree of vulnerability to the impacts of climate change.

Table: 10. Degree of farmers preferred grass and crop species in order to mitigate climate change

\begin{tabular}{|l|l|l|}
\hline Preferred crops and grass & Frequency & Percentage \\
\hline Boloke & 15 & 34.89 \\
\hline Desho & 10 & $23.25 \%$ \\
\hline Masho & 5 & $11.63 \%$ \\
\hline Protein quality maize & 13 & $30.23 \%$ \\
\hline Total & 43 & $100 \%$ \\
\hline
\end{tabular}

Source: (social field survey, 2017)

Table: 10. Degree of farmers preferred tree species in order to mitigate climate change

\begin{tabular}{|l|l|l|}
\hline Preferred trees & Frequency & Percentage \\
\hline Wanza & 18 & $41.86 \%$ \\
\hline Shola & 10 & $23.25 \%$ \\
\hline Grawa & 8 & $18.6 \%$ \\
\hline Warka & 7 & $16.29 \%$ \\
\hline Total & 43 & $100 \%$ \\
\hline
\end{tabular}

Source :( social field survey, 2017)

\section{Awareness of Climate change among experts}

The result indicated that from 10 respondents, there were 9 respondents $(90 \%)$ are those have awareness to climate change. The other 1 respondent $(10 \%)$ are those have on awareness to (Table11)

Table: 11Awareness of climate change among experts

\begin{tabular}{|l|l|}
\hline Awareness to climate change & No and \% of respondents \\
\hline Awareness to climate change & $9(90 \%)$ \\
\hline No awareness to climate changes & $1(10 \%)$ \\
\hline
\end{tabular}

Climate mitigation measures in the study area

The result shoes that there are a lot of mitigation measures are used in the study area reduce cc effects. From these expansions of plantation, waste disposal far away from the living area etc. From 10respondents, there were $9(90 \%)$ said that they have mitigation mangers in their local area. The other 1(10\%) respondents said that as they have mitigation measure (Table 12).

Table: 12. Mitigation measures of experts in the study area.

\begin{tabular}{|l|l|l|}
\hline Mitigation measures & Respondent & Percentage \\
\hline Have mitigation measures & 9 & $90 \%$ \\
\hline Have no mitigation measures & 1 & $10 \%$ \\
\hline
\end{tabular}

\section{CONCLUSION}

The study was about the perception of community on Climate change in case of shara kebele on Arba Minch zuria wereda. In the study awareness of Climate change in the shara kebele like local communities and experts 
were responded. From the respondent's majority of expert have good degree awareness to climate change and its impacts. Because most of the experts in the Kebele have consideration of the climate change issue in their activity plans. By contrast, local communities have less awareness to climate change and its impacts. This is because of lack of training in the area, lack of Imitativeness to have knowledge about climate change. The impact of climate change on agriculture, forest and health sector was also responded, from this agriculture and health sector is severely affected by the impact of climate change. Since agriculture is the major share of their economy and health is the expression of their living status, the changing effect is challenge most of the peoples resides in the area. The adaptation mechanism used by the local community was also responded. From this, majority of the community have an indigenous knowledge of using plantation and terracing systems. And the remaining respondents were used tolerant crop planting, sweet potato and compost.

Based up on the above conclusions the following recommendations are needed to reduce the impact of climate change.

The ever-increasing climate variability and change impacts would require institutional involvement.

$\checkmark$ Empowering local community with information and education: creating and expanding awareness about climate change, its consess and consequence by providing reliable and up-to date information to take appropriate adaptive measures.

$\checkmark \quad$ In the future, similar studies should be conducted which adequately address the issue the issue the of venerability to Climate Change, adaption and the relative merit of each adaption option to better guide policy option for adaptation to climate change and variability.

$\checkmark$ Both governmental and nongovernmental organization should give emphasis to the awareness of the Climate Change.

$\checkmark$ At the range of Shara Kebele, there should be more research study conducted on this topic in the future.

\section{REFERENCES}

Adane, k, 2009. Assessment of local community understanding of and responses to cc: the case of fourkebele of Diredewa city. M.A thesis, Addis Abeba University.

Aklilu and Alebachew,2010,2010. An over view of cc impacts and responses in E Ban, A.W. Van den and H.S. Hawkins, 2000.Agricultural Extension, second edition, Blackwell Science, UK

Banjade, M.R., 2003. Local Perception and Use of Information for Forest user groups: case studies from Dhankunta District, Nepal. MSc. Thesis, Tropical Forestry, Wageningen University, Ethiopia.

Barrett, C. B., T. Reardon, and P. Webb (2001). Non-farm income diversification and household livelihood strategies in rural Africa: concepts, dynamics, and policy implications. Food Policy 26:315-331.

Bates,B.C.Z.Wkundzewicz,S.wu and J.P palutikof,Eds, 2008.Cc change and water: Technical paper of the interGovernmental panel once, IPCC secretariat, Geneva.

Bewuket, A, 2010. Analysis of farmers" perception and adaption to climate change and variability: the case of choke mountain, East Go jam M.A thesis, Addis Ababa university

CIER, 2008.Climate change and first nations of 60: impacts, adaption, and priorities. Climate change adaptation and mitigation in the food and agriculture sector, technical background document from the expert consultation held on 5 to 7 march 2008 fao,rome

David, K, 2009. Coping with climate change: understanding local communities " knowledge and their coping strategies to climate change".

Ellis, F., (2000).Rural Livelihoods and Diversity in Developing Countries.Hurber.M., K.M., Bugmann, and Dordrecht, R .A. M., 2005, Global Change and Mountain Regions: An Overview of Current Knowledge. Springer, The Netherlands.

FAO 2007. Adaption to climate change in agriculture, forests and fisheries: perspective, frame work and priorities Rome, Italy.

Haakansson, M, 2009. When the rains fail: Ethiopia's struggle against climate change. 20 IPCC, 2007: Climate Change 2007: Synthesis Report. Contribution of Working Groups I, II and III to the Fourth Assessment Report of the Intergovernmental Panel on Climate Change [Core Writing Team, Pachauri, R.K and Reisinger, A. (eds.)]. IPCC, Geneva, Switzerland, 104 pp.

IPCC,1998. The regional impacts of climate change: An assessment of vulnerability. Cambridge: Cambridge University press.

Klein, and G. Yohe, (2001). Adaptation to climate change in the context of sustainable development and equity. In McCarthy, J.J., Canziani, O., Leary, N.A., Dokken, D.J. and White, K.S., eds, Climate change 2001: impacts, adaptation and vulnerability. IPCC Working Group II. Cambridge: Cambridge University Press, 877-912

NAPA $\backslash$ MOE (2010). Thematic Working Group Summary Report. National Adaptation Programme of Action 
(NAPA), Ministry of Environment, Government of Nepal.

NCCF, 2009 proceedings of the first National adaption program of action (NAPA) of Ethiopia. Addis Abeba, Ethiopia

Saarinen, T.F., and 1976 Environmental planning: perception and behavior. Houghton Mifflin Comp. Boston

SAGUN, 2009.Climate Change Impacts on Livelihoods of Poor and Vulnerable Communities and Biodiversity Conservation: A Case Study in Banke, Bardia, Dhading and Rasuwa District of Nepal.

Smit, B., O. Pilifosova, I. Burton, B. Challenger, S. Huq, R.J.T. Strengthened Actions for Governance in Utilization of Natural Resources Program, CARE Nepal, Kathmandu, Nepal, 56 pp.

UNFCCC, 2007.Climatechange: impacts, vulnerabilities and adaptation in developing Countries. Climate change secretaries (UNFCCC): Bonn,Germany.

WHO, 200.CC and human health: Impacts and Adaptaion on.Geneva, Adapting to climate change to sustain food security. WIRES climate change. 